Article

\title{
Effects of Multifunctional Rural Land Use on Residents' Wellbeing: Evidence from the Xinzhou District of Wuhan City, China
}

\author{
Weiyan $\mathrm{Hu}^{1}{ }^{1}$, Siyu Zhang ${ }^{1}$, Yan Song ${ }^{2}$, Tian Liu ${ }^{1}$, Yingchao Lin ${ }^{3}{ }^{\circledR}$ and Anlu Zhang ${ }^{1, *}$ \\ 1 College of Public Administration, Huazhong Agricultural University, Wuhan 430070, China; \\ huweiyan@mail.hzau.edu.cn (W.H.); zhangsy@webmail.hzau.edu.cn (S.Z.); \\ Liutian0808@webmail.hzau.edu.cn (T.L.) \\ 2 Chinese Urban Program, the University of North Carolina at Chapel Hill, Chapel Hill, NC 27514, USA; \\ ys@email.unc.edu \\ 3 School of Construction Management and Real Estate, Chongqing University, Chongqing 400045, China; \\ cquclyc@cqu.edu.cn \\ * Correspondence: zhanganlu@mail.hzau.edu.cn
}

Received: 30 August 2018; Accepted: 16 October 2018; Published: 19 October 2018

\begin{abstract}
The purpose of this article is to analyze the effects of multifunctional rural land use (MRLU) on residents' wellbeing. A questionnaire survey on 805 rural residents in 64 villages of the Xinzhou District of Wuhan city in China, and estimators of OLS, ordered logit, and ordered probit were employed. The Shannon's H index and Simpson's Reciprocal Index are used to measure MRLU and the life satisfaction approach is used to measure wellbeing. An inverted-U pattern is observed in the relationship between MRLU and wellbeing, and another finding of the study is the threshold of MRLU. The article contributes to the literature by integrating MRLU into wellbeing analysis from a spatial-separated form, and deepens the relationship between MRLU and the residents' wellbeing. MRLU is characterized by differences and a moderation, which can provide a reference for profiling rural land use planning and for designing land-use policy, and for prompting rural sustainable development.
\end{abstract}

Keywords: land management; multifunctional rural land use; residents' wellbeing; self-reported life satisfaction

\section{Introduction}

Studying the effects of multifunctional rural land use on wellbeing can guide policymakers to design rural land use planning/policy, and ultimately also prompt rural sustainable development through sustainable land use. With the acceleration of human economic and social development as well as urbanization, natural-led land use in forests, grasslands, and wetlands have rapidly been converted to human-led land use in agricultural land and urban construction land [1]. Land use conflicts around the world are getting more and more intense. In the meantime, the land use/cover change has caused great damage to all of the land ecosystems' structures [2]. Consequently, the land-ecosystems' functions and services have declined and been degraded [3], which poses a threat to contemporary human society and future generations, in terms of wellbeing and benefits from the land ecosystems [4]. In response, both developed and developing countries have taken measures involving environmental protection and spatial planning to alleviate the effects of the international crisis [5]; also, multifunctional agriculture has been commonly recognized by the Food and Agriculture Organization of the United Nations (FAO), European Union (EU), and Economic Cooperation Organization (ECO). For example, the intensive use of agricultural land in the European Union, Norway, Switzerland, and Japan has gradually shifted 
from the traditional production-oriented use to the multifunctional use [6]. Additionally, in the United States, in agricultural subsidy policies, more attention has been paid to the quality of the environmental, as well as to farmland preservation programs and multifunctional farmland use $[7,8]$.

Since the implementation of the reform-and-open policy, China has achieved great progress in increasing the residents' wellbeing and income with urbanization and industrialization. However, the rapid urbanization and industrialization has caused an enormous loss of high-quality agricultural land, which has been converted to urban use and non-farm use. The rural eco-environment has been damaged seriously and the increasing gap between urban-rural residents' income still remains; social conflicts often occur in rural areas. China has been facing challenges of balancing economic development, urbanization, food security, and eco-environmental protection $[9,10]$. Since 2007, the Chinese central government has set up a series of policies in order to protect the 'farmland redline', with 1.2 million $\mathrm{km}^{2}$, and to protect the 'ecological redline', emphasizing ecological civilization construction. In 2011, the State Council issued the 'main functional area plans', and provinces, cities, and counties proposed their own main functional area planning to designate key development zones, major agricultural products producing areas, and key ecological zones. In 2012, the 18th National Congress of the Communist Party of China set a goal of territorial space optimization and of the coordinated development of "San Sheng Kong Jian", followed by stating the following specific requirements, "space for production is used intensively and efficiently, space for living is livable and moderate in size, and ecological space is bright in mountain and limpid in water." In 2017, the 19th National Congress of the Communist Party of China put forward Rural Revitalization Strategies to accurately grasp the scientific connotation of rural revitalization, and to explore the various functions and values in the rural areas, which was embodied again in the Rural Revitalization Strategic Planning (2018-2022) issued by the Central Committee and the State Council of the Communist Party of China in September 2018. Land use planning is a vital means to preserve farmland and ecological land. Since 1986, China has experienced three rounds of overall land use planning successively, and overall land use planning has been carried out at a country, provincial, city, county, and town level. Currently, the fourth round of the overall land use planning is underway, and it is extending to the level of the rural area. The intention of these policies and of land use planning is to coordinate and synergize the rural space in production, living, and ecology named "San Sheng Kong Jian", by improving the rural residents' wellbeing, based on a people-oriented guideline. The countryside is a base for achieving sustainable development and an ideal experimental field for implementing national policies [11]. Therefore, the research on the effects of multifunctional rural land use on residents' wellbeing at the smaller scale can provide references for rural land use planning, as well as for agriculture/rural sustainable development.

Theoretically, factors contributing to individual's wellbeing have received much attention. In addition to income, gender, age, health status, education, income, and community neighborhood relationships, trust in government, other public positives and negatives involving air quality [12], airport noise [13], climate [14], floods [15], drought [16] and housing conditions [17] are also very important determinants of wellbeing. Recently, many studies on relationships between scenic landscapes [18], ecosystem diversity, agricultural land resources [19], multifunctional land use and wellbeing have been completed, from different scales of analyses, and the relationships still remain unclear. At the global scale, wellbeing increased with decreasing land-based ecosystem service [20], while at regional or local scales, that was different. For example, Ambrey et al. [21] used a life satisfaction approach to study the ecosystem diversity of South East Queensland, Australia, from an individual micro-scale, and it was found that maintaining or improving the existing ecosystem service level would increase the individuals' welfare. In another study, it was found that amenity has a non-linear positive impact on the residents' wellbeing [18]. We have combined the concepts of multifunction to test the impact of cultivated land, including paddy fields and dry land, on the farmers' wellbeing from a micro-individual scale [19]. The relationship between land-based ecosystem and wellbeing in the literature showed a difference because of measurement of multifunctional land use, wellbeing and the scale of analyses. 
Concerning to measurement of multifunctional land use, a sustainable impact assessment was mainly focused [20,21]. For example, the SENSOR project, under the EU's 6th framework, supported by the Global Land Project (GLP) in 2004, proposed an interdisciplinary concept of multifunctional land use, and developed a set of model tools to assess whether multifunctional land use in Europe could be sustainable, and a paradigm for the multifunctional analysis of land use was framed [21] in order to do research on the land use change impact assessment [22], policy impact simulation of the land function change [23], and an impact assessment of the land use policies on sustainable development [24]. Meanwhile, constructing an evaluation index system from a macro scale to evaluate the multifunctional land use and its dynamic changes [25], analyzing the relationship between land use and land function [26,27], and exploring the socio-economic environment welfare effect of multifunctional land use [28] are greatly heated fields. Turning to the measurement of wellbeing, the approaches have shifted from economic concepts such as GDP/GNP, money income, consumption to a more multidimensional one in terms of economic wellbeing and non-economic wellbeing such as the human development index, the theory of Sen's Feasible Ability as a composite index. Also, it was increasingly recognized that a new measurement was needed. More recently, self-reported happiness and life satisfaction has been employed to measure multidimensional wellbeing, as a single index. A new approach of self-reported happiness and life satisfaction asks people how happy they feel that they themselves are, and is a rational measurement of the emotional state of people's living conditions [21]. In summary, land is a composite system with multi-functions in production, living, and ecology, which are interrelated and mutually unified [29]. From the perspective of spatial form, multifunctional land use consists of two types, space-separated and space-integrated. These depend on an analytical scale. When a plot or only one type of land use (e.g., farmland) is concerned, it is referred to as a space-integrated form of multifunctional land use, and when a region with a boundary and multi-purpose land use is concerned, it is referred to as space-separated. The existing literature mostly focuses on space-integrated multifunctional land use, including our recent study [19], and the research on space-separated multifunctional land use, especially at the village scale, still remains limited. Hence, the impact of space-separated multifunctional land use on rural residents' welfare still needs further exploration.

In this article, the Shannon's H index and Simpson's Reciprocal Index are used to measure multifunctional land use (MRLU) and the self-reported life satisfaction approach is used to measure wellbeing. A relationship between MRLU and wellbeing is tested at the village scale. The structure of this paper is as follows: this section introduces the background and literature review. Section 2 introduces a theoretical basis, hypothesis, and analytical framework. Section 3 describes the research methods and models, and Section 4 is the research area and data processing. Section 5 reports the research results. The final section is the conclusion and discussion.

\section{Analytical Framework and Hypothesis}

Wellbeing refers to joys and happiness, and is generally viewed as a description of people's life situation [30]. Human wellbeing is defined by the Millennium Ecosystem Assessment (MA )with five components: basic materials, health, security, good social relations, and freedom of choice and actions [20]. Multifunctional land use means that, in addition to the traditional production function in producing food and materials, land is used for other non-commodity production functions in the economic, environmental, social, and cultural domains. Human wellbeing is closely linked to the natural environment, and the sustainable supply of the ecosystems is an important guarantee for human wellbeing [31]. The land use system is a complex artificial ecosystem. Land use/cover change directly affects the structures and functions of land-based ecological processes via the material cycle, energy exchange, biological production, and biodiversity, and, consequently, affects the overall ecosystem service function, human wellbeing, and value [32]. The synergies of multifunctional land use could well beautify the rural natural environment and improve the rural residents' wellbeing in 
a sustainable way [33]. And human wellbeing and value from the ecosystems also play a vital role in land use/cover change, in reverse order.

With the rapid development of industrialization and urbanization, the human demand from land-based ecosystems is characterized by the diversity of the functions of culture and the ecoenvironment, except for food and materials, not only in quantity but also in quality. Therefore, because of the shortage of land resources, there is inefficient competition or trade-off between the land use functions, which could impact human wellbeing in a negative way under the context of an increase in land fragmentation, technical restrictions and the low ability to govern the land-based ecosystem service [34]. For example, the relationship between the functions in the production and the eco-environment are competitive, and there are trade-offs between the function in the production and people, as well as between the function of people and the eco-environment [35]. Land use/cover changes cause conflicts in the value of the regional ecosystem services [36]. Reclaiming grasslands to farmland might increase the value of the ecosystem in the supply of agricultural products, but it might decrease its value in maintaining water and soil regulation and supporting services [37]. Agricultural working land plays an important role in conserving water sources and regulating climate, however, the surrounding ecosystems would compete with crops for water, sunlight, nutrients, and pollination, and would impact their functions in production [38]. The rapid expansion of urban land and industrial land has occupied and eroded a large amount of high-quality cultivated land. There is a serious contradiction between economic development and the protection of cultivated and resources [39]. In addition, each of the five components of wellbeing at some scale is in relation to some land-based ecosystem services. And satisfaction with "basic materials" mainly provided by the activities of agricultural land use and partly of industrial and mining construction land is regarded as the most fundamental variables among the five components of human wellbeing [40]. In that case, improvement of land used for production mainly in basic materials might increase human wellbeing, while ecological land use functions in other components of wellbeing has not yet worked.

Hence, the research hypothesis is proposed as follows (Figure 1): multifunctional rural land use might have an impact on residents' wellbeing, and there might be an 'inverted U-shaped' relationship between multifunctional rural land use and the residents' wellbeing.

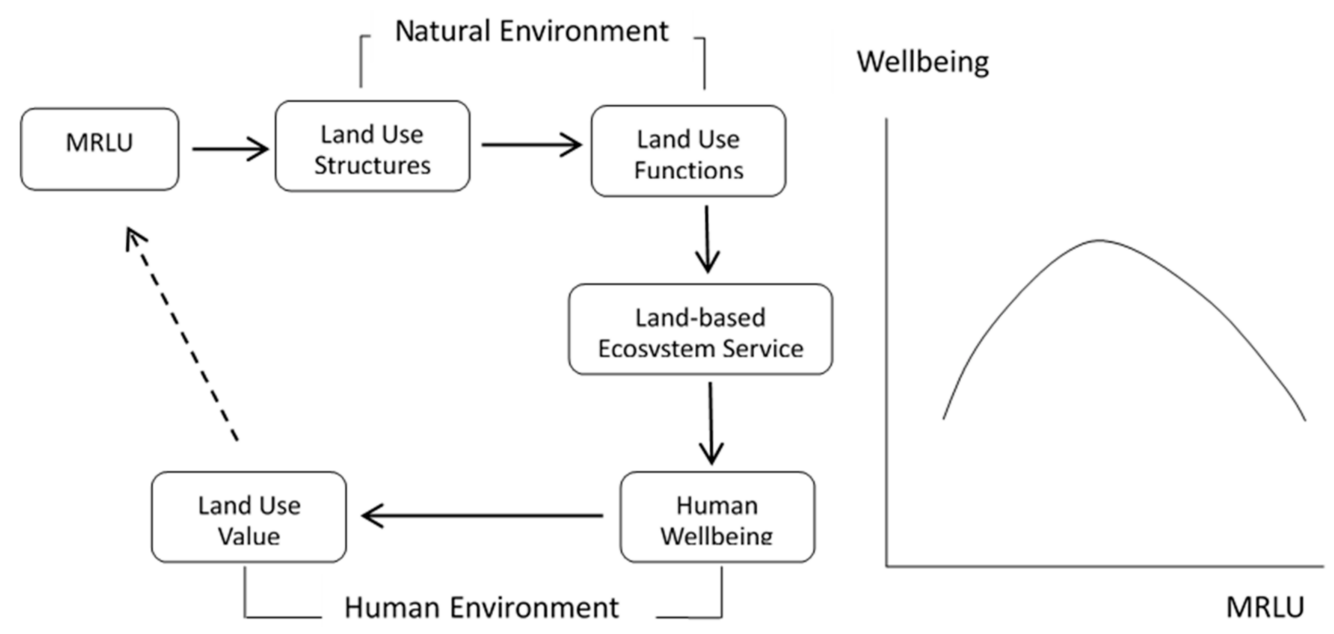

Figure 1. Theoretical hypothesis on Relationships between Multifunctional Rural Land Use (MRLU) and Human Wellbeing.

\section{Empirical Model and Methods}

\subsection{Econometric Model}

Studying the determinants of wellbeing is very important to probe into the effects of multifunctional rural land use on wellbeing. Many studies have found that men are less happy 
than women [41], but the conclusions of Ambrey and Fleming are contrary to this [21]; age and life satisfaction are expressed as a 'U-shaped' relationship, and when a person is 30 or 40 years old, they have the least happiness [42]. Poor health significantly reduces life satisfaction [42]. Education has a negative impact on life satisfaction [43], and although education does not directly affect life satisfaction, it indirectly improves life satisfaction through the positive effects of the creation and control of human capital and social capital [44]; some studies have also shown that education increases personal life satisfaction [31]. Community neighborhood relationships and social composition, such as interpersonal relationships in a community; trust in others, police, courts, and government; and the size of houses are also mentioned [17,45]. In our current study, trust in the sub-government in the process of policy implementations, such as agricultural subsidies, farmers' medical insurance, and land expropriation with compensation, are important factors [19]. In this article, MRLU is integrated into wellbeing analysis. An analytical framework has been formed to do empirical testing (Figure 2).

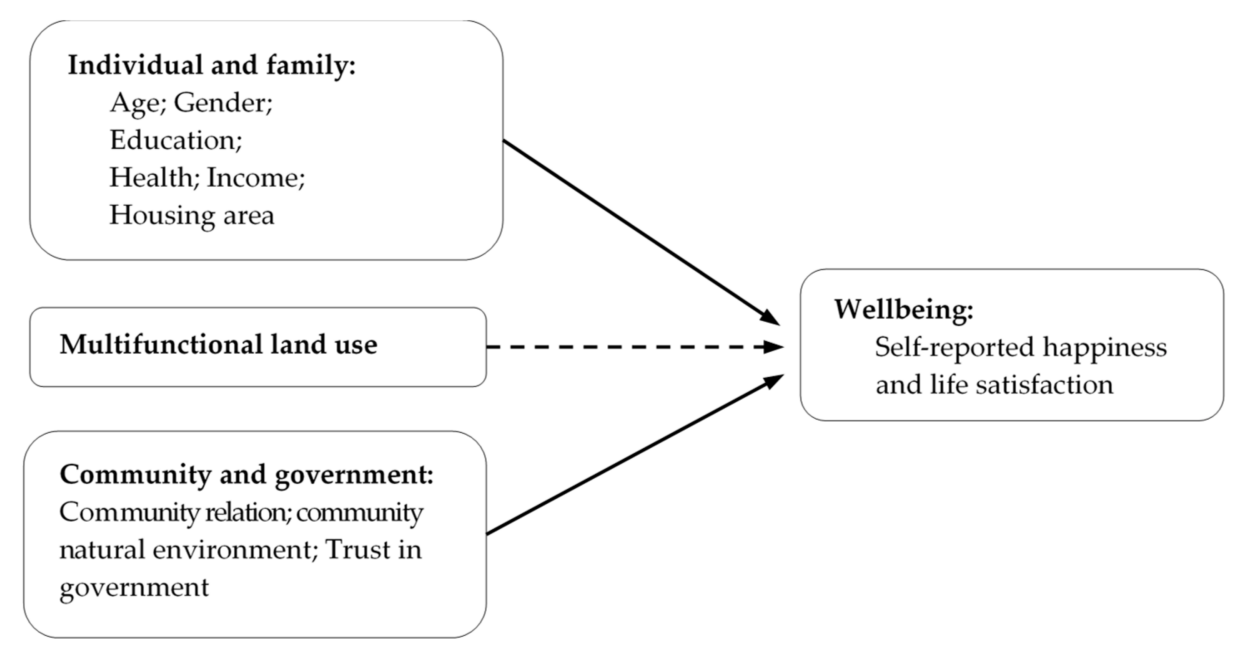

Figure 2. Diagram of Multifunctional Rural Land Use and Other Factors Contributing to Self-Reported Wellbeing. Notes: In the solid arrow, the determinants of wellbeing have been studied in the existing literature, and impacts of the multifunctional rural land use on wellbeing (the dotted arrow) will be tested in this paper.

The specification of an empirical econometric model, adapted from Brereton et al. [46] and Hu et al. [19], takes the following form:

$$
\mathrm{U}_{\mathrm{ij}}=\beta_{0}+\beta_{1} \cdot x_{i, j}+\beta_{2} \cdot \ln y_{i, j}+\beta_{3} \cdot z_{i, j}+\beta_{4} \cdot \rho_{i, j}+\varepsilon_{i, j}
$$

where $U_{\mathrm{ij}}$ denotes the self-reported happiness and life satisfaction of an individual, $i$, in a region, $j$; $x_{i, j}$ represents the multifunctional rural land use level of the region, $j$, where an individual, $i$, lives; $y_{i, j}$ is the family income of an individual, $i$, in a region, $j$; the vector $z_{i, j}$ captures the individual-level determinants, including age, gender, education, health, housing area, and so on; $\rho_{i, j}$ is a vector of the neighborhood and government, such as community relation, community natural environment, and trust in government; and $\varepsilon_{i, j}$ is the error term.

Using variables rather than algebraic symbols in this article, and considering the robustness of models, we propose the following formula (2) with the variable of MRLU, formula (3) with variables of MRLU and income, and formula (4) with all variables, where the variable definition and measurement are continued in Section 3.2.

$$
\begin{gathered}
\mathrm{LS}=\beta_{0}+\beta_{1} \cdot \mathrm{MRLU}_{t-1}+\beta_{2} \cdot \mathrm{MRLU}_{t-1}{ }^{2}+\varepsilon \\
\mathrm{LS}=\beta_{0}+\beta_{1} \cdot M R L U_{t-1}+\beta_{2} \cdot M R L U_{t-1}{ }^{2}+\beta_{9} \cdot \ln \operatorname{INCOM}_{t}+\varepsilon
\end{gathered}
$$




$$
\begin{aligned}
\mathrm{LS}= & \beta_{0}+\beta_{1} \cdot \mathrm{MRLU}_{t-1}+\beta_{2} \cdot M R L U_{t-1}^{2}+\beta_{3} \cdot G E N D+\beta_{4} \cdot A G E+\beta_{5} \cdot A G E^{2} \\
& +\beta_{6} \cdot H E A L T+\beta_{7} \cdot E D U C A+\beta_{8} \cdot S U B G O+\beta_{9} \cdot \ln (I N C O M)_{t}+\varepsilon
\end{aligned}
$$

\subsection{Variable Definition and Measurement}

The variables' definition and expected direction of Formulas (2)-(4) are shown in Table 1. The variable of multifunctional rural land use is measured through the Shannon index in Formula (5) and the Simpson Reciprocal Index in Formula (6). The Shannon index focuses on the diversity of land use functions, while the Simpson Reciprocal Index is mostly based on even quantities of multi-functions [47-49]. Other variables come from questionnaire surveys in 64 villages.

$$
H_{0}=-\sum p_{i j} \ln p_{i j}
$$

where $H_{0}$ is the Shannon index; $p_{i j}$ represents the ratio of the area of the type, $i$, of land use function at the location, $j$, to the total land area at the location, $j$.

$$
\mathrm{SRI}=\frac{1}{\sum\left(n_{i j} / N\right)^{2}}
$$

\begin{tabular}{|c|c|c|}
\hline Variable & Variable Definition & Expected Direction \\
\hline LS & $\begin{array}{l}\text { Life satisfaction is divided into very satisfied, satisfied, general, } \\
\text { dissatisfied, very dissatisfied, coded } 5,4,3,2,1\end{array}$ & \\
\hline MRLU & $\begin{array}{l}\text { Multifunctional rural land use: the Shannon Index and the Simpson } \\
\text { Reciprocal Index in the forum (3) and (4) }\end{array}$ & $+/-$ \\
\hline GEND & Male $=1$, female $=0$ & $+/-$ \\
\hline AGE & Ages $<16,(16,25),(26,35),(36,45),(46,55),>56$ coded $1,2,3,4,5,6$ & $+/-$ \\
\hline HEALT & $\begin{array}{l}\text { Individual health status is divided in to five grades: very healthy, } \\
\text { relatively healthy, average, poor, and very poor, coded } 5,4,3,2,1\end{array}$ & + \\
\hline EDUCA & $\begin{array}{l}\text { Education is divided in to five grades: Illiterate or semi-literate, } \\
\text { elementary school, junior high school, high school (secondary school), } \\
\text { college or above, coded } 1,2,3,4,5\end{array}$ & + \\
\hline SUBGO & $\begin{array}{l}\text { Trust in sub-government: Measured by satisfaction of policy } \\
\text { implementation, very satisfied, satisfied, general, dissatisfied, very } \\
\text { dissatisfied, coded } 5,4,3,2,1\end{array}$ & + \\
\hline INCOM & Annual average household disposable income (yuan) & + \\
\hline NEIGH & $\begin{array}{l}\text { Satisfaction of neighborhood status, and it is divided into five grades: } \\
\text { very satisfied, satisfied, general, dissatisfied, and very dissatisfied, } \\
\text { coded } 5,4,3,2,1\end{array}$ & + \\
\hline HOUSE & Total family housing area $\left(\mathrm{m}^{2}\right)$ & + \\
\hline ENVIR & $\begin{array}{l}\text { Surrounding natural environment satisfaction is divided into five } \\
\text { grades: very satisfied, satisfied, general, dissatisfied, very dissatisfied, } \\
\text { coded } 5,4,3,2,1 \text {. }\end{array}$ & + \\
\hline
\end{tabular}

where SRI is the Simpson reciprocal index; $n_{i j}$ is the area of the type, $i$, of the land use functions at the position, $j$; and $N$ is the total number of land use functions.

Table 1. Variable description.

Based on the policy of "San Sheng Kong Jian" in China, the functions of land use are divided into functions of production, living, and eco-environment [50]. Function in production refers to the land being used for the products and supplies from human activities of agriculture, industry, and commerce, which are available mainly in cultivated, industrial, and mining construction land. Urbanized land and rural settlements can provide the functions of carrying and guaranteeing human settlements. 
In addition, the eco-environmental function of land-based ecosystems, such as forest land, grassland, and, to some extent, farmland, includes regulating, maintaining, and guaranteeing ecological security.

On the measurement of wellbeing, in economics, Pigou [51] restricted his own research field to whether money is directly or indirectly related to wellbeing, which is called economic objective wellbeing. Often, wellbeing has been equated with the material position of a country/region/individual, and has been measured by its gross domestic/national production (GDP/GNP) or per capita annual income [52,53]. Later, wellbeing was expanded as a measure of the consumption of goods and services, which was recognized to be more articulated and closer to the pleasant or unpleasant real experience that a person feels from the enjoyment of goods or services. Nevertheless, economic wellbeing measured by income or consumption does not capture all of the aspects of human life, and indicators such as education, health and nutrition, environmental degradation, social participation, and trust in the government have been elaborated on to be included in multidimensional wellbeing, such as the environmentally adjusted domestic product and the human development index $[19,30]$. The European Commission's "GDP and beyond" calls for socio-economic surveys that provide indicators on the different dimensions of wellbeing and for techniques able to measure the complexity that arises from not limiting oneself to just one dimension of wellbeing beyond money income. Another approach to measuring multidimensional wellbeing is mostly based on the theory of Sen's Feasible Ability. Although the indices are useful, they are not transparent, for example, the choice of indices used, the issue of collinearity amongst indicators, and the weight assigned to different categories [30]. More recently, self-reported happiness and life satisfaction has been employed to measure multidimensional wellbeing, as a single index. A new approach of self-reported happiness and life satisfaction is a rational measurement of the emotional state of people's living conditions [21]. In this article, we used a self-reported measure of life satisfaction as our dependent variable.

\section{Study Area and Data}

\subsection{Study Area}

In this article, the study area is the Xinzhou District, a suburban area in the northeastern Wuhan city, the capital of Hubei Province, China (Figure 3). The Xinzhou District has more than ten street agencies, three towns, one economic development zone, and one scenic tourist area. The total territorial area is $1500.66 \mathrm{~km}^{2}$, of which the land area accounts for $82 \%$ and the water body area accounts for $18 \%$. Arable land is a major type of land use, and its area is $48,800 \mathrm{hm}^{2}$. In 2016, the population of residents in the Xinzhou District was 894,800, and the urbanization rate based on the permanent residents was $51.21 \%$.

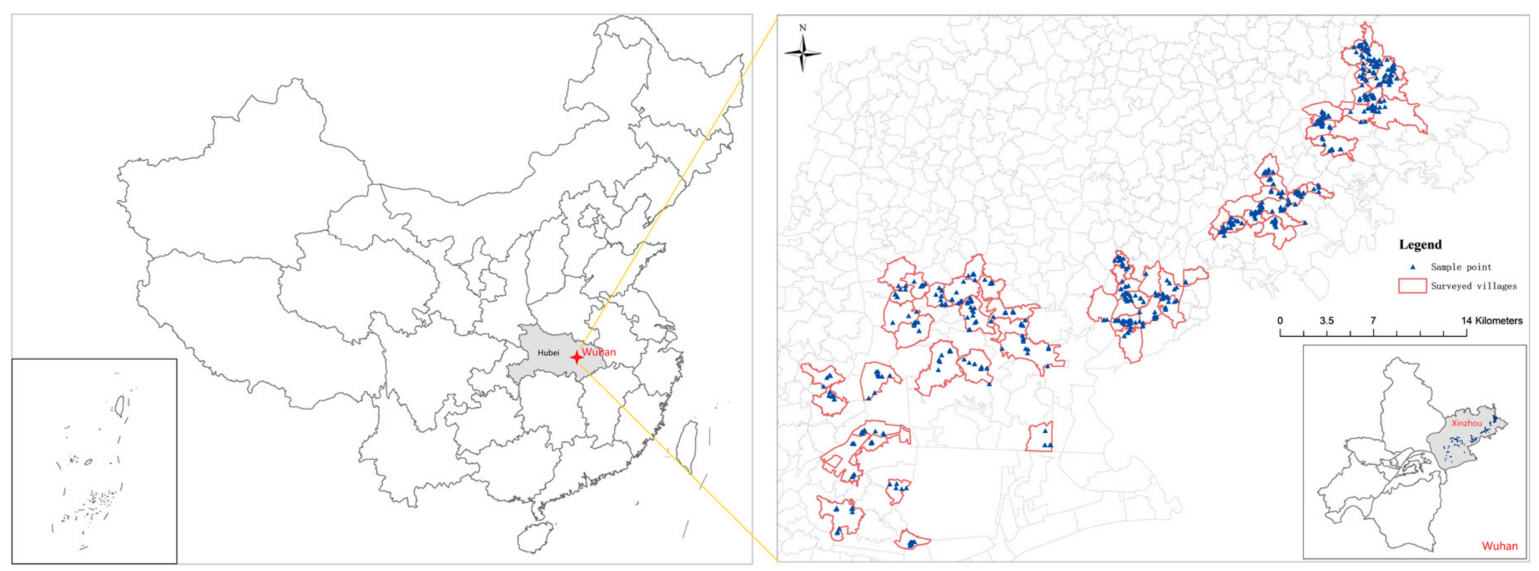

Figure 3. The study area and spatial distribution of data.

Xinzhou District is the first pilot area for the construction of new countryside and new communities in Wuhan. Since the implementation of the "Home Construction Action Plan", Xinzhou 
District has actively explored the implementation of the transformation of "City in the Village" and "Village in the Park" in the towns of Zhucheng and Yangluo. Most recently, new rural construction in the Xinzhou District has made a great progress, and ten beautiful villages and twenty-five livable villages have been built. In 2006, Wuhan's government issued the 'Wuhan Urban Agriculture Development Plan (2006-2020)', which put forward a basic layout planning, with "six regions, four centers, and two systems". A new pattern of urban agriculture with an ecological belt, industrial block, basic sheet, and spillover circle was formed to integrate the first, second, and third industries. As a demonstration zone for national modern agriculture, and to be an ecologically new city, Wuhan's government has designated the Xinzhou District, establishing an eco-agriculture tourism demonstration zone. The multiple use of rural land has gradually emerged, which is of great significance to the sustainable development of Xinzhou District.

\subsection{Data}

Two types of data are employed in this paper. One is the Landsat TM/ETM remote sensing image data from 1995, 2000, 2005, 2010 and 2015 (spatial resolution is $30 \mathrm{~m} \times 30 \mathrm{~m}$ ), and vector data of rural administrative divisions in Xinzhou District in 2013. The data processing flow is as follows: (1) Image processing of the remote sensing image data of the five periods, including image enhancement, fusion, etc., and geometric registration of the image in combination with field measured data and related geographic maps. (2) Human-computer interaction interpretation to obtain land use data, and assessing the data quality by Kappa Index. The requirements of the accuracy for cultivated land, construction land and other land uses are not less than $85 \%, 80 \%$ and $75 \%$ respectively. And land use data of the five periods are obtained. And the other is questionnaire survey data. From November 2015 to November 2016, after a trial survey, we selected the Xinzhou District as the study area, and conducted a random face-to-face questionnaire survey; 805 valid questionnaires of 820 questionnaires from 64 villages in the study area were obtained. The survey contents mainly covered age, gender, health, education, family income, policy implementation satisfaction, and community neighborhood status. We coded the geographic information of the residential location of respondents (Figure 3).

We used the self-reported life satisfaction to measure the residents' wellbeing as a dependent variable in the empirical model. Responses to the question, "generally speaking, how satisfied would you say you are with your life as a whole? Completely very satisfied, satisfied, general, dissatisfied, very dissatisfied?" were assigned integer values from 5 to 1 . In order to avoid the possible behavior of a strategic reaction in the survey, we designed the question to be at the start of the questionnaires. According to the statistical results, $73.42 \%$ of the respondents reported a life satisfaction score of 3 or more, with an average of 3.23 and a standard deviation of 1.079 .

Concerning the statistical analysis of the other variables, males and females account for $56.48 \%$ and $43.52 \%$ of the respondents, respectively, and the proportion of males and females in the study area is similar to that of the suburbs of Wuhan. A large number of young and middle-aged laborers have migrated from the surveyed area, while the middle-aged and elderly remained in the rural area. Therefore, the respondents' age is concentrated above 46 years old, accounting for $77.5 \%$, and the education achievement in the study area is lower than that of Wuhan's suburbs.

We used SPSS 22.0 software to perform the missing value processing and reliability analysis on the questionnaire data. The analysis results show that the reliability test value of the questionnaire is $80.0 \%$, the validity test value is $83.9 \%$, and the overall reliability meets the standard requirement, which proves that the data fits the imminent econometric model.

\section{Results}

\subsection{Changes of Multifunctional Rural Land Use}

Using ArcGIS 10.2, we did a raster reclassification of the land use raster maps of the Xinzhou District in 1995, 2000, 2005, 2010 and 2015, based on the classification standard of 'San Sheng Kong 
Jian', and then calculated the Shannon index from Formula (5) and the Simpson Reciprocal Index in Formula (6) to explore the changes of the multifunctional rural land use over the past 20 years in the study area (Figures 4 and 5).

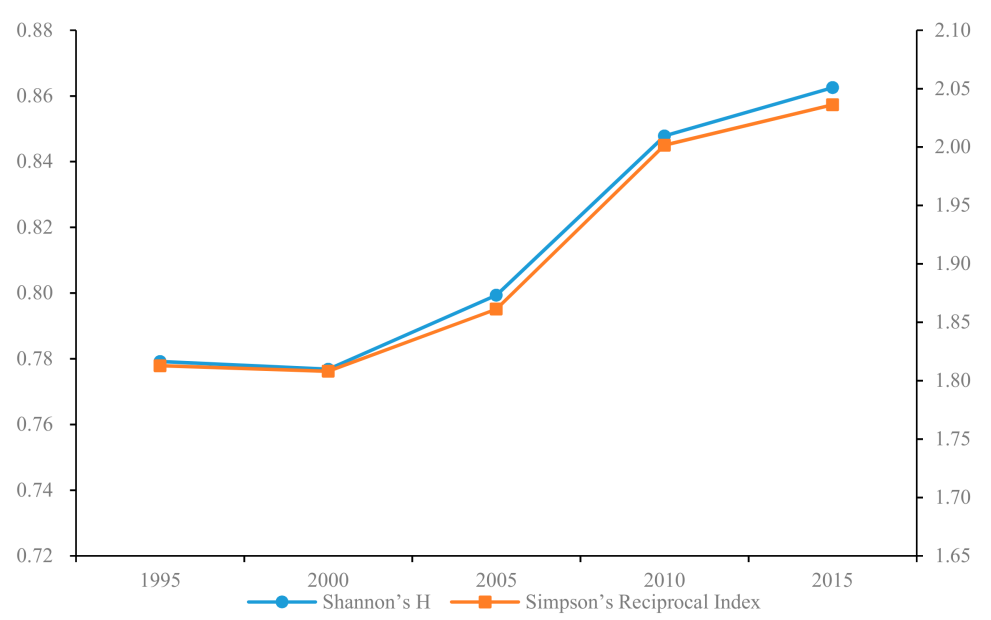

Figure 4. Temporal Changes of the Shannon's H and the Simpson's Reciprocal Index of multifunctional rural land use in study area, from 1995 to 2015.
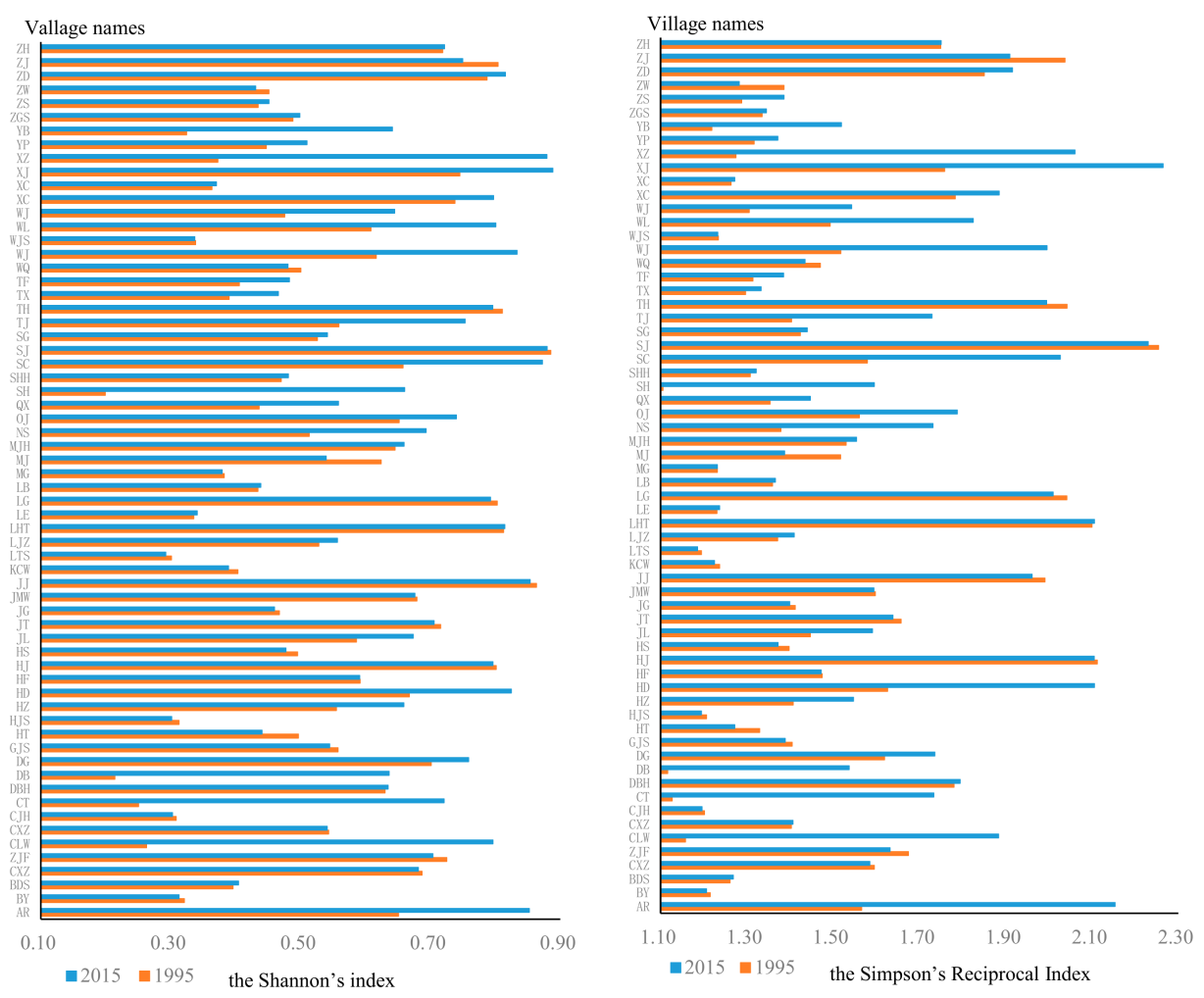

Figure 5. Spatial differences of the Shannon's index and the Simpson's Reciprocal Index of multifunctional land use in the surveyed area, from 1995 to 2015.

Figures 4 and 5 show that, during the 20 years from 1995 to 2015, the level of multifunctional land used in the study area generally increased. The Shannon index and Simpson's Reciprocal Index increased from 0.779 and 1.813 to 0.863 and 2.036, respectively, and their growth rate was $10.783 \%$ and $12.300 \%$, respectively. The years 2005 to 2010 showed a trend of the fastest growth. There were differences in the multifunctional rural land use in the different villages. In 2015, the range from the Shannon index and the Simpson Reciprocal Index of the 64 villages surveyed was 0.5958 and 1.0793, 
respectively. Multifunctional land use on the village scale has seen great changes. The Shannon index of 38 villages showed an increasing trend, with an average rate of $39.615 \%$, while that of 26 villages showed a decreasing trend, with an average rate of $2.886 \%$. Also, the Simpsons Reciprocal Index of 39 villages showed an increasing trend with an average rate of $15.850 \%$, while that of 25 villages showed a decreasing trend with an average rate of $1.981 \%$.

\subsection{Econometric Results}

The variable of self-reported life satisfaction is ordered; it was more appropriate to employ the ordered logit model. In a study on happiness, Ferrer-i-Carbonell and Frijters found that OLS estimates are very close to the results of the ordered probit or the ordered logit models [54,55]. Therefore, in this article, we used the ordered logit, the ordered probit model, and the OLS estimators, with stata12 software (Tables 2 and 3).

For more detail, see Appendix A Tables A1 and A2. The variance inflation factor (VIF) and the correlation coefficient (less than 0.4 ) between all of the variables shows that there is no multicollinearity, which is consistent with the independence hypothesis. We performed a BP test and a White test for the models of the Shannon index and the Simpson Reciprocal Index, in order to test the homoscedasticity hypothesis. The test results showed there is no heteroscedasticity.

Table 2. Results of ordered logit estimation.

\begin{tabular}{|c|c|c|c|c|c|c|}
\hline \multirow{2}{*}{ Variable } & \multicolumn{3}{|c|}{$H_{0}$} & \multicolumn{3}{|c|}{ SRI } \\
\hline & Model 1 & Model 2 & Model 3 & Model 4 & Model 5 & Model 6 \\
\hline MRLU & $\begin{array}{c}17.8443^{* * * *} \\
(2.7904)\end{array}$ & $\begin{array}{c}15.9266^{* * * *} \\
(2.8108)\end{array}$ & $\begin{array}{c}16.5829^{* * * *} \\
(2.8708)\end{array}$ & $\begin{array}{c}15.8023 * * * \\
(2.5509)\end{array}$ & $\begin{array}{c}14.1836^{* * *} \\
(2.5768)\end{array}$ & $\begin{array}{c}15.2838^{* * *} \\
(2.6492)\end{array}$ \\
\hline MRLU-squared & $\begin{array}{c}-13.6782 * * * \\
(2.3415)\end{array}$ & $\begin{array}{c}-12.2942 * * * \\
(2.3588)\end{array}$ & $\begin{array}{c}-12.5899 * * * \\
(2.4020)\end{array}$ & $\begin{array}{c}-4.5370 * * * \\
(0.7595)\end{array}$ & $\begin{array}{c}-4.0956 * * * \\
(0.7674)\end{array}$ & $\begin{array}{c}-4.3695^{* * *} \\
(0.7876)\end{array}$ \\
\hline GEND & & & $\begin{array}{l}-0.3051 \text { ** } \\
(0.1375)\end{array}$ & & & $\begin{array}{c}-0.3230 * * \\
(0.1374)\end{array}$ \\
\hline AGE & & & $\begin{array}{c}-1.8732 * * * \\
(0.5245)\end{array}$ & & & $\begin{aligned}- & 1.8348^{* * *} \\
& (0.5211)\end{aligned}$ \\
\hline AGE-squared & & & $\begin{array}{c}0.2328 * * * \\
(0.0567)\end{array}$ & & & $\begin{array}{c}0.2257 * * * \\
(0.0564)\end{array}$ \\
\hline HEALT & & & $\begin{array}{c}0.1879 * * \\
(0.0739)\end{array}$ & & & $\begin{array}{l}0.1897^{* *} \\
(0.0738)\end{array}$ \\
\hline EDUCA & & & $\begin{array}{l}0.2262 * * \\
(0.0894)\end{array}$ & & & $\begin{array}{c}0.2379 * * * \\
(0.0896)\end{array}$ \\
\hline SUBGO & & & $\begin{array}{l}0.1177 * \\
(0.0624)\end{array}$ & & & $\begin{array}{c}0.2156^{* * *} \\
(0.0638)\end{array}$ \\
\hline $\ln (\mathrm{INCOM})$ & & $\begin{array}{c}0.5910^{* * *} \\
(0.0852)\end{array}$ & $\begin{array}{c}0.5278^{* * *} \\
(0.0861)\end{array}$ & & $\begin{array}{c}0.6107^{* * *} \\
(0.0851)\end{array}$ & $\begin{array}{c}0.5278^{* * *} \\
(0.0861)\end{array}$ \\
\hline NEIGH & & & $\begin{array}{c}0.2696^{* * *} \\
(0.0896)\end{array}$ & & & $\begin{array}{c}0.2370 * * * \\
(0.0894)\end{array}$ \\
\hline HOUSE & & & $\begin{array}{c}0.0019 * * \\
(0.0009)\end{array}$ & & & $\begin{array}{c}0.0019 * * \\
(0.0009)\end{array}$ \\
\hline ENVIR & & & $\begin{array}{c}0.5042 * * * \\
(0.0952)\end{array}$ & & & $\begin{array}{c}0.5126^{* * *} \\
(0.0955)\end{array}$ \\
\hline $\begin{array}{l}\text { pseudo } \mathrm{R}^{2} \\
\text { log likelihood } \\
\text { sample size }\end{array}$ & $\begin{array}{c}0.0247 \\
-1143.9565 \\
805\end{array}$ & $\begin{array}{c}0.0457 \\
-1119.3837 \\
805\end{array}$ & $\begin{array}{c}0.1026 \\
-1052.5792 \\
805\end{array}$ & $\begin{array}{c}0.0194 \\
-1150.1505 \\
805\end{array}$ & $\begin{array}{c}0.0419 \\
-1123.8061 \\
805\end{array}$ & $\begin{array}{c}0.1024 \\
-1052.8158 \\
805\end{array}$ \\
\hline
\end{tabular}

Note: explained variable: LS (life satisfaction); key explanatory variables: MLU (Shannon index, Simpson Countdown Index); ${ }^{*}, * *$, and ${ }^{* * *}$ are the $10 \%, 5 \%$, and $1 \%$ significant level, respectively; standard error is in parentheses. 
Table 3. Results of ordered probit and OLS estimation.

\begin{tabular}{ccccc}
\hline & \multicolumn{2}{c}{$\mathrm{H}_{\mathbf{0}}$} & \multicolumn{2}{c}{ SRI } \\
\cline { 2 - 5 } & Ordered Probit & OLS & Ordered Probit & OLS \\
\hline MRLU & $10.0706^{* * *}$ & $8.9197^{* * *}$ & $8.8277^{* * *}$ & $7.7938^{* * *}$ \\
& $(1.6628)$ & $(1.4470)$ & $(1.5265)$ & $(1.3338)$ \\
\hline MRLU-squared & $-7.6914^{* * *}$ & $-6.8101^{* * *}$ & $-2.5324^{* * *}$ & $-2.2343^{* * *}$ \\
& $(1.3949)$ & $(1.2161)$ & $(0.4554)$ & $(0.3982)$ \\
\hline Controlled variable & Controlled & Controlled & Controlled & Controlled \\
\hline pseudo R & 0.1014 & & 0.0997 & \\
log likelihood & -1054.0237 & & -1055.9946 & \\
F & & 23.24 & & 22.72 \\
$\mathrm{R}^{2}$ & 805 & 0.2604 & 805 & 0.2561 \\
sample size & 805 & 805 \\
\hline
\end{tabular}

Note: Explained variable: LS (Life Satisfaction); Main explanatory variables: rural land use (MRLU) including the Shannon index and the Simpson Reciprocal Index; Controlled variables include the rest of variables in Model 3 of Table $2 ;{ }^{* * *}$ denotes the level of significance $1 \%$; the standard error is in parentheses.

Table 2 shows the results of ordered logit estimator. The pseudo $\mathrm{R}^{2}$ of the models is similar to that found in related studies [56-58], and the significance of regression coefficient is stable. In Model 1 and Model 4, the explanatory variables of the Shannon index or the Simpson Reciprocal Index and their square terms were considered. In Model 2 and Model 5, the variable of annual household income was added. In Model 3 and Model 6, more variables were considered.

According to Section 2, there might be a cause-effect relationship between multifunctional rural land use and residents' wellbeing. In order to avoid this kind of econometric problem, we used previous values of multifunctional rural land use instead of current values of residents' wellbeing, as well as other variables.

The coefficient of the MRLU variable is significantly positive, and that of the square term is significantly negative, which indicates that there is a robust 'inverted U-shaped' relationship between the multifunctional rural land use and the residents' wellbeing. On the low level of the multifunctional rural land use, the residents' wellbeing might increase significantly with the level of multifunctional rural land use. When the level of the multifunctional rural land use reaches a certain point, the residents' wellbeing shows a downward trend with the level of the multifunctional rural land use. The multifunctional land use might beautify the rural natural environment and improve the rural residents' wellbeing in a sustainable way. However, there might be different main functions of rural land in each village. In some villages, production function is more important to welfare than other functions, and inefficient competition and trade-off of production function and other different functions of land use might have a negative impact on economic growth, and in the end might decrease the residents' wellbeing. It is also an important reason for why the high level of multifunctional rural land use results in a high degree of land fragmentation. The fragmentation of land will have a negative impact on scale operations, and then the welfare will decrease. Besides, there is a time lag effect after the rising of multifunctional rural land use before human wellbeing is affected.

In terms of the individual characteristics of the rural residents, women's life satisfaction is significantly higher than that of men. There is a clear 'U-shaped' relationship between age and self-reported life satisfaction. An individual's health is significantly positively correlated with life satisfaction and the residents' education. Concerning the community characteristics, the life satisfaction of farmers in better neighborhoods is correspondingly higher, and the residents' satisfaction for the village environment also significantly positively influences their life satisfaction. Trust in the sub-government in the process of implementing policy would also increase the residents' wellbeing. The household income and housing area were significantly positively correlated with life satisfaction. 


\subsection{Threshold for Multifunctional Rural Land Use}

The threshold value means a minimum or maximum value that an effect can produce. In this article, the threshold value of the multifunctional rural land use refers to the turning point of the 'inverted U-shaped' curve between multifunctional rural land use and residents' wellbeing. The residents' wellbeing would increase with the multifunctional rural land use until it reaches a threshold, and then the wellbeing would decrease with the multifunctional rural land use. The turning point is the optimal level of multifunctional rural land use. Based on the econometric results by the ordered logit estimator, we calculated the threshold value for multifunctional rural land use expressed by the Shannon index and the Simpson Reciprocal Index. The threshold values are 0.709 and 1.749 , respectively. The threshold value serves as a benchmark for the guidance for policy-decisions.

In an oriented two-dimensional coordinate system, the x-axis is level of multifunctional rural land use from the Shannon index and the Simpson Reciprocal Index, and the $y$-axis is self-reported life satisfaction. According to the threshold value and the average life satisfaction in the villages, we got a four quadrant diagram to diagnose the villages' distribution maps (Figure 6), as follows: (I) multifunctional rural land use level < the threshold value, and mean village life satisfaction > overall mean; (II) multifunctional rural land use level $>$ the threshold value, and mean village life satisfaction > overall mean; (III) multifunctional rural land use level $>$ the threshold value, and mean village life satisfaction < overall mean; and (IV) multifunctional rural land use level < the threshold value, and mean village life satisfaction < overall mean. In doing so, we investigated the villages' location on the four-quadrant diagram, as well as in which villages multifunctional rural land use has a negative/positive impact on the residents' wellbeing.

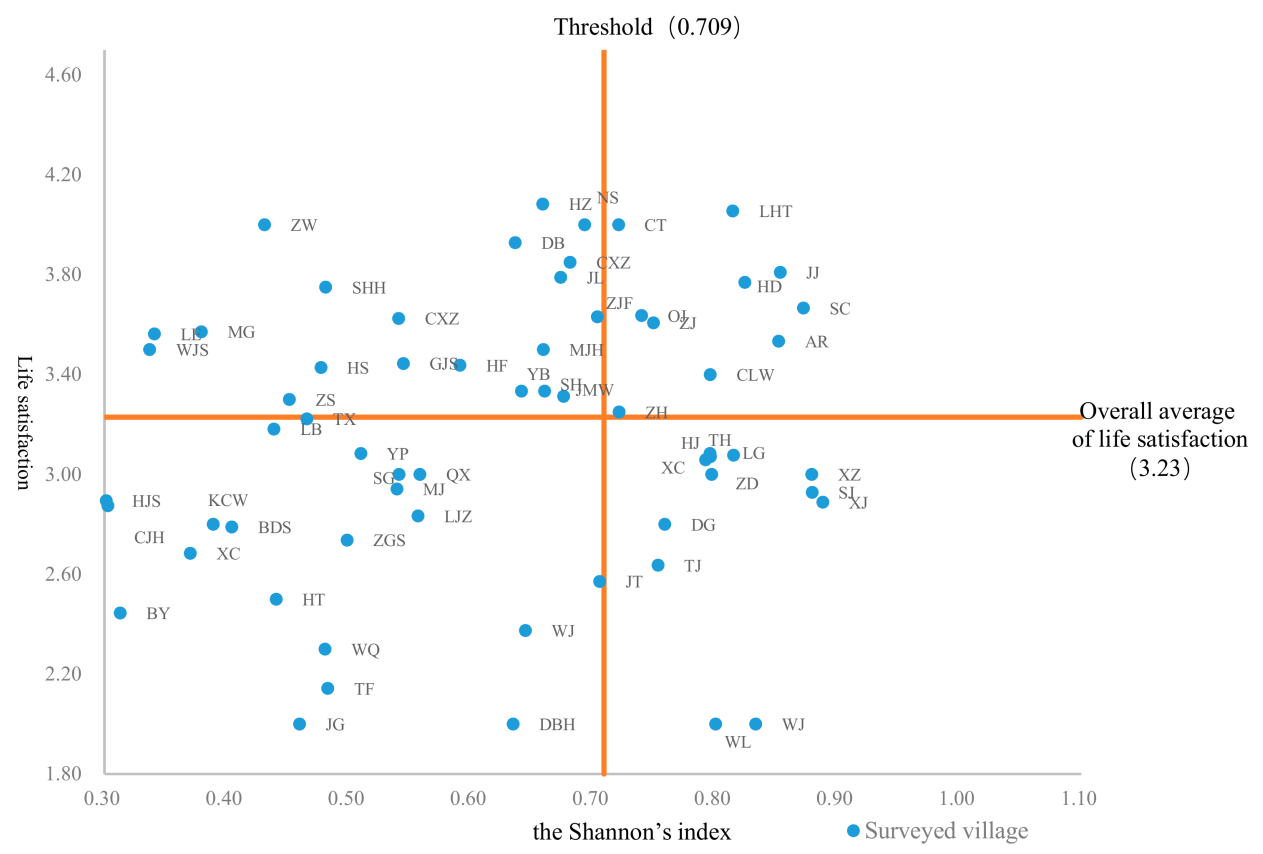

Figure 6. Cont. 


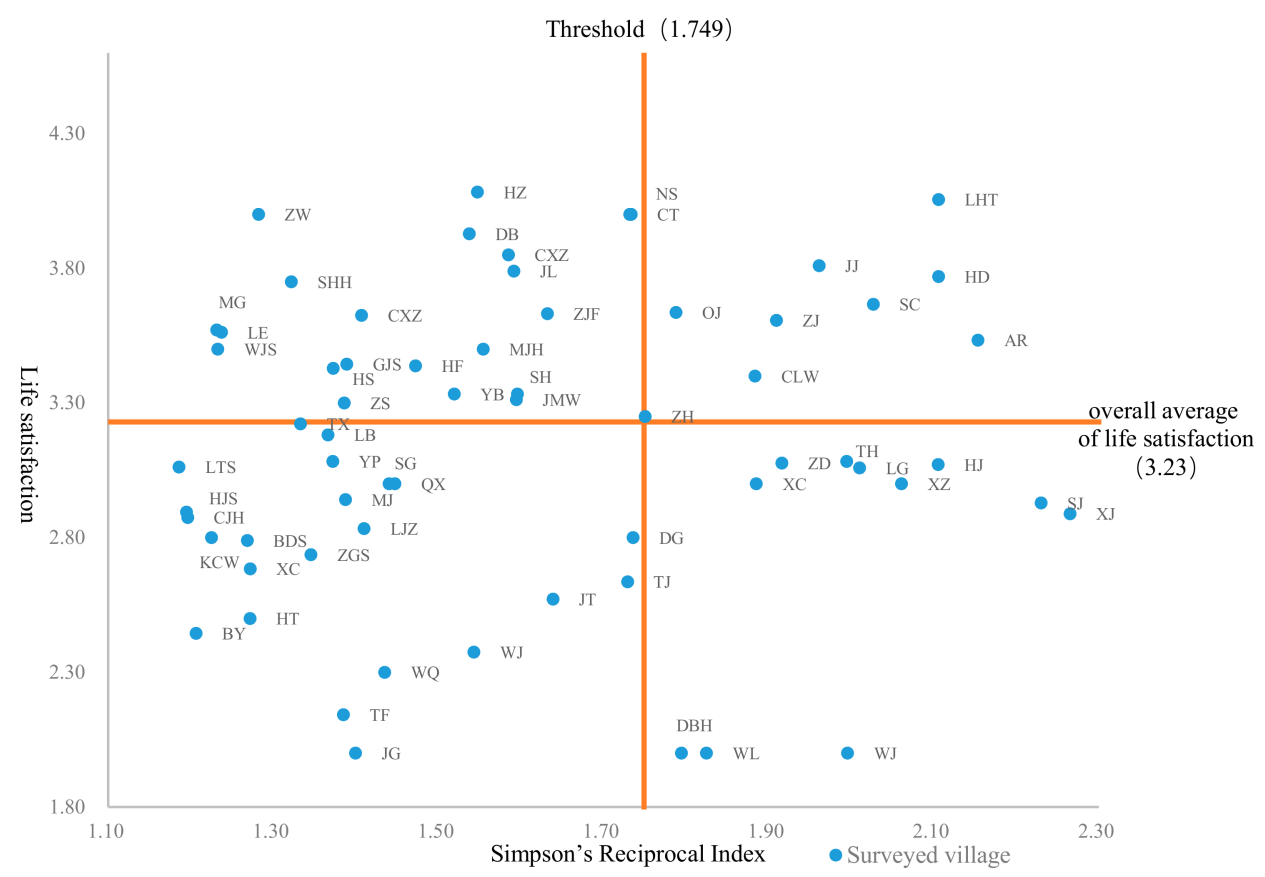

Figure 6. The thresholds of multifunctional rural land use and the distribution of villages. (Based on land use data in 2015 and surveyed data in 2015-2016.).

\section{Conclusions and Discussion}

From the perspective of the space-separated form, we employed the life satisfaction approach to explore the impact of multifunctional rural land use on residents' wellbeing at the village scale, and our conclusion is as follows: Firstly, since 1995, the level of multifunctional rural land use, measured by the Shannon index and the Simpson Reciprocal Index has increased at a rate of $10.783 \%$ and $12.300 \%$, respectively, in the study area. Also, the overall level of multifunctional rural land use is on the rise. However, there are differences in the changes of multifunctional rural land use in the different villages. Some villages' levels of multifunctional rural land use are increasing, while others are decreasing.

More importantly, the effects of multifunctional rural land use on residents' wellbeing is non-linear, and there is a significant inverted U-shaped relationship between multifunctional rural land use and residents' wellbeing. The threshold value for multifunctional rural land use, represented by the Shannon index and the Simpson Reciprocal Index, is 0.709 and 1.749, respectively. For example, when the level of multifunctional rural land use by the Shannon index is less than 0.709, the residents' wellbeing might increase with the multifunctional rural land use, and when the level of multifunctional rural land use by the Shannon index is more than 0.709 , the residents' wellbeing might decrease with the multifunctional rural land use. Lastly, according to the threshold value and the average life satisfaction in the villages, the four-quadrant diagram is drawn to diagnose in which villages multifunctional rural land use has a negative/positive impact on residents' wellbeing.

On the whole, in this article, multifunctional rural land use and its effects are characterized by the differences in the villages, and there is also a moderate multifunctional rural land use, which is of great importance for policymakers to revitalize the rural area through multifunctional rural land use and management in the study area, as well as beyond. Hence, we suggest that, firstly, the integration of the natural characteristics of rural land, as well as different and a moderation in multifunctional rural land use should be paid attention, in order to implement a policy of multifunctional rural land use and management, such as rural land comprehensive rearrangement and rural land use planning, so as to reconstruct and improve the development of 'San Sheng Kong Jian' in a harmonious way. In addition, the multifunctional rural land use policy would be people-centered, aiming at increasing the rural residents' wellbeing. We would expand the pathways of multifunctional rural land use, advancing the 
level of multifunctional rural land use in the villages with a level lower than the threshold. For the villages with a level of multifunctional rural land use more than the higher threshold, the land use patterns and structure would be readjusted, the ecological recovery of ecological land would be strengthened in a serious regulation, and the development intensities and size would be restricted so as to protect ecological land, such as forest land and water. Concerning the individuals' scale, because farmers are the direct actors of multifunctional rural land use, policymakers should give publicity especially to farmers for multifunctional rural land use, and should extend environmentally friendly technology for rural land use, improving initiative in farmers' participation in multifunctional rural land use.

In this article, employing a mixed method with qualitative and quantitative methods, from the perspectives of villages, we extended the existing literature on the determinants of human wellbeing, and probed into the relationship between multifunctional rural land use and residents' wellbeing. We found that there is an inverted U-shaped relationship between the multifunctional rural land use and residents' wellbeing. Then, we put forward a concept of threshold value of multifunctional rural land use and diagnosed whether villages had a high/low level of multifunctional rural land use and a high/low residents' wellbeing. Our research would provide a basis for compiling the national land use planning in the villages as well as for designing a land use policy.

The measurement of multifunctional rural land use is vital to the research. In this article, we tried to employ multiple approaches, such as the Shannon index and the Simpson Reciprocal Index, based only on the dimensions of land use, restricted to the current data. Land use is a process and outcome of human activities, which, to some extent, could respond to land use functions; however, theoretically, detailed land covers, including the human landscape and natural landscape, might be better data to use in order to measure multifunctional rural land use. Although we induced the mechanism of the impacts of multifunctional rural land use and residents' wellbeing, and found an inverted U-shaped relationship between the multifunctional rural land use and residents' wellbeing in the study area, the specific mechanism of the impacts should be investigated in future research; for example, the residents' benefits from material income or from mental spirit in multifunctional rural land use. In the latter, the ongoing medical agri-tourism throughout the world might be a potential industry. In doing so, in-depth case studies of villages are a very interesting topic to probe into the specific mechanism of the impacts of multifunctional rural land use and residents' wellbeing.

Author Contributions: W.H. conceptualized the framework of this study and determined the method. S.Z. contributed to methodology, data collection, and result analysis. Y.S. revised the manuscript. T.L. and Y.L. participated in the acquisition of data and participated in data processing. A.Z. approved the final version. Moreover, several native English speakers contributed to paper revision before submission this time.

Funding: This research would not have been possible without sponsorship from the National Natural Science Foundation of China (grant number 71673105; grant number 71303087; and grant number 71873053).

Acknowledgments: We thank the anonymous referees for their comments on the paper. All of the errors and omissions remain our own.

Conflicts of Interest: The authors declare no conflict of interest. 


\section{Appendix A}

Table A1. Variance expansion factor test.

\begin{tabular}{ccc}
\hline Variable & VIF & 1/VIF \\
\hline The multifunctional use level of Rural Land (MRLU) is represented by the Shannon index \\
\hline AGE & 1.29 & 0.7735 \\
NEIGH & 1.28 & 0.7837 \\
ENVIR & 1.27 & 0.7867 \\
HEALT & 1.21 & 0.8263 \\
EDUCA & 1.16 & 0.8621 \\
SUBGO & 1.12 & 0.8961 \\
GEND & 1.11 & 0.9049 \\
ln(INCOM) & 1.06 & 0.9401 \\
HOUSE & 1.05 & 0.9516 \\
MRLU & 1.04 & 0.9615 \\
Average VIF & 1.16 & \\
\hline The multifunctional use level of Rural Land (MRLU) is represented by the Simpson Reciprocal Index \\
\hline AGE & 1.30 & 0.7721 \\
ENVIR & 1.28 & 0.7842 \\
NEIGH & 1.27 & 0.7889 \\
HEALT & 1.21 & 0.8262 \\
EDUCA & 1.16 & 0.8625 \\
SUBGO & 1.12 & 0.8907 \\
GEND & 1.10 & 0.9051 \\
ln(INCOM) & 1.07 & 0.9390 \\
HOUSE & 1.05 & 0.9518 \\
MRLU & 1.04 & 0.9659 \\
Average VIF & 1.16 & \\
\hline
\end{tabular}

Table A2. Correlation coefficient matrix.

\begin{tabular}{|c|c|c|c|c|c|c|c|c|c|c|}
\hline & MRLU & GEND & AGE & HEALT & EDUCA & SUBGO & $\ln (\mathrm{INCOM})$ & NEIGH & HOUSE & ENVIR \\
\hline \multicolumn{11}{|c|}{ The multifunctional use level of Rural Land (MRLU) is represented by the Shannon index } \\
\hline MRLU & 1.0000 & & & & & & & & & \\
\hline GEND & -0.0662 & 1.0000 & & & & & & & & \\
\hline AGE & 0.0070 & 0.1631 & 1.0000 & & & & & & & \\
\hline HEALT & 0.0425 & -0.0773 & -0.3164 & 1.0000 & & & & & & \\
\hline EDUCA & 0.0686 & 0.1859 & -0.2460 & 0.1401 & 1.0000 & & & & & \\
\hline SUBGO & -0.0884 & 0.0452 & 0.1054 & 0.0513 & -0.0180 & 1.0000 & & & & \\
\hline $\ln (\mathrm{INCOM})$ & 0.1201 & -0.0001 & -0.0157 & 0.1105 & 0.1131 & 0.0763 & 1.0000 & & & \\
\hline NEIGH & -0.0502 & -0.0426 & 0.0318 & 0.1954 & -0.0017 & 0.2539 & 0.0261 & 1.0000 & & \\
\hline HOUSE & 0.0353 & -0.0269 & -0.1396 & 0.0248 & 0.0970 & 0.0113 & 0.1438 & 0.0446 & 1.0000 & \\
\hline ENVIR & -0.0369 & 0.0554 & 0.1261 & 0.1525 & 0.0314 & 0.2349 & 0.0517 & 0.4072 & 0.0354 & 1.0000 \\
\hline \multicolumn{11}{|c|}{ The multifunctional use level of Rural Land (MRLU) is represented by the Simpson Reciprocal Index } \\
\hline MRLU & 1.0000 & & & & & & & & & \\
\hline GEND & -0.0675 & 1.0000 & & & & & & & & \\
\hline AGE & -0.0019 & 0.1631 & 1.0000 & & & & & & & \\
\hline HEALT & 0.0465 & -0.0773 & -0.3164 & 1.0000 & & & & & & \\
\hline EDUCA & 0.0659 & 0.1859 & -0.2460 & 0.1401 & 1.0000 & & & & & \\
\hline SUBGO & -0.0915 & 0.0484 & 0.1228 & 0.0443 & -0.0129 & 1.0000 & & & & \\
\hline $\ln (\mathrm{INCOM})$ & 0.0998 & -0.0001 & -0.0157 & 0.1105 & 0.1131 & 0.1046 & 1.0000 & & & \\
\hline NEIGH & -0.0500 & -0.0426 & 0.0318 & 0.1954 & -0.0017 & 0.2391 & 0.0261 & 1.0000 & & \\
\hline HOUSE & 0.0115 & -0.0269 & -0.1396 & 0.0248 & 0.0970 & 0.0285 & 0.1438 & 0.0446 & 1.0000 & \\
\hline ENVIR & -0.0371 & 0.0554 & 0.1261 & 0.1525 & 0.0314 & 0.2431 & 0.0517 & 0.4072 & 0.0354 & 1.0000 \\
\hline
\end{tabular}




\section{References}

1. Rockström, J.; Steffen, W.; Noone, K.; Persson, Å.; Chapin, F.S.; Lambin, E.F.; Lenton, T.M.; Scheffer, M.; Folke, C.; Schellnhuber, H.J.; et al. A safe operating space for humanity. Nature 2009, 461, 472-475. [CrossRef] [PubMed]

2. Sterling, S.M.; Ducharne, A.; Polcher, J. The impact of global land-cover change on the terrestrial water cycle. Nat. Clim. Chang. 2013, 3, 385-390. [CrossRef]

3. Vitousek, P.M.; Mooney, H.A.; Lubchenco, J.; Melillo, J.M. Human Domination of Earth's Ecosystems. Science 1997, 277, 494-499. [CrossRef]

4. Li, S.; Liu, J.; Zhang, C.; Zhao, Z. The Research Trends of Ecosystem Services and the Paradigm in Geography. J. Geogr. Sci. 2011, 66, 1618-1630. (In Chinese)

5. Batten, D.F. Network cities: Creative urban agglomerations for the 21st century. Urban Stud. 1995, 32, 313-327. [CrossRef]

6. Lee, C.; Liao, L.; Chen, Y.; Wang, Y.; Lan, I. Farmland Functions and Use Types Option Under Multfunctional Agricultural Regime. J. TWN Land Res. 2009, 12, 139-162. (In Chinese)

7. Nickerson, C.J.; Hellerstein, D. Protecting rural amenities through farmland preservation programs. Agric. Resour. Econ. Rev. 2003, 32, 129-144. [CrossRef]

8. Hu, W.; Lu, D.; Zhao, Z.; Song, Y. The Logic and Enlightenment of Multi-functional Agricultural Land Protection Policy in America. Rur. Econ. 2015, 18, 121-125. (In Chinese)

9. Zhang, A. Transferable development rights and rural-urban land conversion controlling. China Rur. Surv. 2000, 2, 20-25. (In Chinese)

10. Yu, J. From State-Led Development to Endogenous Development: The Strategic Transformation of Rural and Agricultural Development in Contemporary China. Comp. Econ. Soc. Syst. 2013, 3, 12-25. (In Chinese)

11. Qiao, J.; Zhao, D.; Li, X. Temporal-Spatial Evolution of Agricultural Specialized Villages Development: The Case of Nanyang City, Henan Province, China. Econ. Geogr. 2014, 34, 131-138. (In Chinese)

12. Levinson, A. Valuing public goods using happiness data: The case of air quality. J. Public Econ. 2012, 96, 869-880. [CrossRef]

13. Van Praag, B.M.S.; Baarsma, B.E. Using happiness surveys to value intangibles: The case of airport noise. Econ. J. 2005, 115, 224-246. [CrossRef]

14. Ferreira, S.; Moro, M. On the use of subjective well-being data for environmental valuation. Environ. Resour. Econ. 2010, 46, 249-273. [CrossRef]

15. Luechinger, S.; Raschky, P.A. Valuing flood disasters using the life satisfaction approach. J. Public Econ. 2009, 93, 620-633. [CrossRef]

16. Carroll, N.; Frijters, P.; Shields, M.A. Quantifying the costs of drought: New evidence from life satisfaction data. J. Popul. Econ. 2009, 22, 445-461. [CrossRef]

17. Zhang, F.; Zhang, C.; Hudson, J. Housing conditions and life satisfaction in urban China. Cities 2018. [CrossRef]

18. Ambrey, C.L.; Fleming, C.M. Valuing scenic amenity using life satisfaction data. Ecol. Econ. 2011, 72, $106-115$. [CrossRef]

19. Hu, W.; Zhang, X.; Song, Y.; Shen, L.; Liu, J.; Zhang, A. Life satisfaction approach to farmers' compensation for land acquisition: Empirical study from the suburbs of Wuhan City. Chin. J. Popul. Resour. Environ. 2014, 12, 316-323. [CrossRef]

20. Raudsepp-Hearne, C.; Peterson, G.D.; Tengö, M.; Bennett, E.M.; Holland, T.; Benessaiah, K.; MacDonald, G.K.; Pfeifer, L. Untangling the Environmentalist's Paradox: Why Is Human Well-being Increasing as Ecosystem Services Degrade? Bioscience 2010, 60, 576-589. [CrossRef]

21. Ambrey, C.L.; Fleming, C.M. Valuing Ecosystem Diversity in South East Queensland: A Life Satisfaction Approach. Soc. Indic. Res. 2014, 115, 45-65. [CrossRef]

22. Helming, K.; Diehl, K.; Bach, H.; Dilly, O.; König, B.; Kuhlman, T.; Pérez-Soba, M.; Sieber, S.; Tabbush, P.; Tscherning, K.; et al. Ex ante impact assessment of policies affecting land use, Part A: Analytical framework. Ecol. Soc. 2011, 16, 1-17.

23. Helming, K.; Diehl, K.; Kuhlman, T.; Jansson, T.; Verburg, P.H.; Bakker, M.; Perez-Soba, M.; Jones, L.; Verkerk, P.J.; Tabbush, P.; et al. Ex ante impact assessment of policies affecting Land use, Part B: Application of the analytical Framework. Ecol. Soc. 2011, 16, 1-23. [CrossRef] 
24. Reidsma, P.; König, H.; Feng, S.; Bezlepkina, I.; Nesheim, I.; Bonin, M.; Sghaier, M.; Purushothaman, S.; Sieber, S.; van Ittersum, M.K.; et al. Methods and tools for integrated assessment of land use policies on sustainable development in developing countries. Land Use Policy 2011, 28, 604-617. [CrossRef]

25. Van Broekhoven, S.; Vernay, A.L. Integrating functions for a sustainable urban system: A review of multifunctional land use and circular urban metabolism. Sustainability 2018, 10, 1875. [CrossRef]

26. Wästfelt, A.; Arnberg, W. Local spatial context measurements used to explore the relationship between land cover and land use functions. Int. J. Appl. Earth Obs. Geoinf. 2013, 23, 234-244. [CrossRef]

27. Wang, Z.; Deng, X.; Wong, C. Integrated Land Governance for Eco-Urbanization. Sustainability 2016, 8, 903. [CrossRef]

28. Djanibekov, U.; Villamor, G.B.; Dzhakypbekova, K.; Chamberlain, J.; Xu, J. Adoption of sustainable land uses in post-soviet central Asia: The case for agroforestry. Sustainability 2016, 8, 1030. [CrossRef]

29. Chen, J.; Shi, P. Discussion on Functional Land Use Classificational System. J. B North Univ. 2005, 41, 536-540. (In Chinese)

30. Conceição, P.; Bandura, R. Measuring Subjective Wellbeing: A Summary Review of the Literature; Office of Development Studies, United Nations Development Programme: New York, NY, USA, 2008.

31. Carpenter, S.R.; Mooney, H.A.; Agard, J.; Capistrano, D.; DeFries, R.S.; Diaz, S.; Dietz, T.; Duraiappah, A.K.; Oteng-Yeboah, A.; Pereira, H.M.; et al. Science for managing ecosystem services: Beyond the Millennium Ecosystem Assessment. Proc. Natl. Acad. Sci. USA 2009, 106, 1305-1312. [CrossRef] [PubMed]

32. IGBP Secretariat. Global Land Project—Science Plan and Implementation Strategy. 2005. Available online: https:/ / digital.library.unt.edu/ark:/67531/metadc12009/m2/1/high_res_d/report-53.pdf (accessed on 19 October 2018).

33. Hu, W.; Wei, A.; Zhao, Z.; Zhang, A. Literature Review on Mismatch of Demand and Supply, and Synergies of Multifunctional Agricultural Land. China Land Sci. 2017, 31, 89-97. (In Chinese)

34. Burt, O.R. Econometric Modeling of the Capitalization Formula for Farmland Prices. Am. J. Agric. Econ. 1986, 68, 10-26. [CrossRef]

35. Su, C.-H.; Fu, B.J.; He, C.S.; Lü, Y.H. Variation of ecosystem services and human activities: A case study in the Yanhe Watershed of China. Acta Oecol. 2012, 44, 46-57. [CrossRef]

36. Yang, X.; Tan, M. Changes and Relationships of Arable Land Functions in Beijing in Recent Years. J. Nat. Resour. 2014, 29, 733-743. (In Chinese)

37. Lu, C.H.; Van Ittersum, M.K.; Rabbinge, R. Quantitative assessment of resource-use efficient cropping systems: A case study for Ansai in the Loess Plateau of China. Eur. J. Agron. 2003, 19, 311-326. [CrossRef]

38. Li, S.; Huang, J.; Tichit, M.; Poulot, M.; Petit, C.; Aubry, C. Comparative review of multifunctionality and ecosystem services in sustainable agriculture gol e. Ecol. Econ. 2015, 149, 138-147.

39. Skinner, M.W.; Kuhn, R.G.; Joseph, A.E. Agricultural land protection in China: A case study of local governance in Zhejiang Province. Land Use Policy 2001, 18, 329-340. [CrossRef]

40. Evenson, R.E.; Gollin, D. Assessing the impact of the Green Revolution, 1960 to 2000. Science 2003, 300, 758-762. [CrossRef] [PubMed]

41. Blanchflower, D.G.; Oswald, A.J. Well-being over time in Britain and the USA. J. Public Econ. 2004, 88, 1359-1386. [CrossRef]

42. Frijters, P.; Haisken-DeNew, J.P.; Shields, M.A. Investigating the Patterns and Determinants of Life Satisfaction in Germany Following Reunification. J. Hum. Resour. 2004, 39, 649-674. [CrossRef]

43. Shields, M.A.; Wheatley Price, S.; Wooden, M. Life satisfaction and the economic and social characteristics of neighbourhoods. J. Popul. Econ. 2009, 22, 421-443. [CrossRef]

44. Helliwell, J.F. How's life? Combining individual and national variables to explain subjective well-being. Econ. Model. 2003, 20, 331-360. [CrossRef]

45. Elgar, F.J.; Davis, C.G.; Wohl, M.J.; Trites, S.J.; Zelenski, J.M.; Martin, M.S. Social capital, health and life satisfaction in 50 countries. Heal. Place 2011, 17, 1044-1053. [CrossRef] [PubMed]

46. Brereton, F.; Clinch, J.P.; Ferreira, S. Happiness, geography and the environment. Ecol. Econ. 2008, 65, 386-396. [CrossRef]

47. Plieninger, T.; Bieling, C.; Ohnesorge, B.; Schaich, H.; Schleyer, C.; Wolff, F. Exploring futures of ecosystem services in cultural landscapes through participatory scenario development in the Swabian Alb, Germany. Ecol. Soc. 2013, 18, 261-272. [CrossRef] 
48. Raudsepp-Hearne, C.; Peterson, G.D.; Bennett, E.M. Ecosystem service bundles for analyzing tradeoffs in diverse landscapes. Proc. Natl. Acad. Sci. USA 2010, 107, 5242-5247. [CrossRef] [PubMed]

49. Stürck, J.; Verburg, P.H. Multifunctionality at what scale? A landscape multifunctionality assessment for the European Union under conditions of land use change. Landsc. Ecol. 2017, 32, 481-500. [CrossRef]

50. Zhang, H.; Xu, E.; Zhu, H. An ecological-living-industrial land classification system and its spatial distribution in China. Resour. Sci. 2015, 37, 1332-1338. (In Chinese)

51. Pigou, A. The Economics of Welfare; Macmillan and Co.: London, UK, 1938.

52. Knack, S.; Keefer, P. Does social capital have an economic payoff? A cross-country investigation. Q. J. Econ. 1997, 112, 1251-1288. [CrossRef]

53. Beugelsdijk, S.; van Schaik, T. Social capital and growth in European regions: An empirical test. Eur. J. Political Econ. 2005, 21, 301-324. [CrossRef]

54. Ferrer-i-Carbonell, A.; Frijters, P. How important is methodology for the estimates of the determinants of happiness? Econ. J. 2004, 114, 641-659. [CrossRef]

55. Ferrer-i-Carbonell, A. Income and well-being: An empirical analysis of the comparison income effect. J. Public Econ. 2005, 89, 997-1019. [CrossRef]

56. Zou, T.; Su, Y.; Wang, Y. Examining Relationships between Social Capital, Emotion Experience and Life Satisfaction for Sustainable Community. Sustainability 2018, 10, 2651. [CrossRef]

57. Di Fabio, A.; Kenny, M.E. Academic relational civility as a key resource for sustaining well-being. Sustainability 2018, 10, 1914. [CrossRef]

58. Wang, E.; Kang, N.; Yu, Y. Valuing Urban Landscape Using Subjective Well-Being Data: Empirical Evidence from Dalian, China. Sustainability 2017, 10, 36. [CrossRef]

(C) 2018 by the authors. Licensee MDPI, Basel, Switzerland. This article is an open access article distributed under the terms and conditions of the Creative Commons Attribution (CC BY) license (http:/ / creativecommons.org/licenses/by/4.0/). 